\title{
EKSTRAKSI ANTIOKSIDAN Spirulina sp. DENGAN MENGGUNAKAN METODE ULTRASONIKASI DAN APLIKASINYA UNTUK KRIM KOSMETIK
}

\author{
Siti Agustina, Novi Nur Aidha, dan Eva Oktarina \\ Balai Besar Kimia dan Kemasan, Kementerian Perindustrian RI \\ Jl. Balai Kimia I Pekayon, Pasar Rebo, Jakarta Timur \\ E-mail: tinaratujaya@yahoo.com
}

Received: 6 Agustus 2018; revised: 9 Agustus 2018; accepted: 18 Oktober 2018

\begin{abstract}
ABSTRAK
EKSTRAKSI ANTIOKSIDAN Spirulina sp. DENGAN MENGGUNAKAN METODE ULTRASONIKASI DAN APLIKASINYA UNTUK KRIM KOSMETIK. Spirulina mengandung bahan aktif sebagai antioksidan, yang dapat digunakan untuk industri farmasi, kosmetik dan pangan. Antioksidan dapat dihasilkan dari proses ekstraksi. Penelitian ini bertujuan untuk mengekstraksi Spirulina sp untuk mendapatkan antioksidan dengan menggunakan metoda ultrasonikasi serta mengaplikasikannya pada krim kosmetik. Tahapan metode penelitian ini adalah: Ekstraksi dengan ultrasonikasi, menggunakan variabel waktu sonikasi selama 15 menit, 30 menit dan 45 menit; variable pelarut yaitu air dan etanol; identifikasi jenis antioksidan; analisis kandungan senyawa antioksidan dan pembuatan sediaan krim kosmetik. Variable pada pembuatan krim yaitu kadar ekstrak 0,1\% dan 0,2\%; serta waktu sonikasi selama 15 menit dan 30 menit. Pada proses ekstraksi Spirulina, waktu sonikasi yang menghasilkan antioksidan optimum adalah 15 menit, dengan kandungan antioksidan sebesar 452,87 $\mu \mathrm{M}$, aktivitas antioksidan sebesar 70,27\%, kandungan beta-karoten sebesar 15,98 mg/kg dan rendemen sebesar 37,15\%. Aplikasi pada krim kosmetik optimum pada kondisi sonikasi 15 menit dan kadar ekstrak $0,2 \%$ dengan karakteristik krim yaitu kadar beta-karoten 4,85 mg/kg; kandungan antioksidan 16,83 $\mu \mathrm{M}$; stabil selama penyimpanan dan cycling test; berwarna kuning, tidak berbau, tekstur halus, dan homogen; $\mathrm{pH} 7$; serta cemaran mikroorganisme di bawah ambang batas sehingga aman digunakan. Hasil ekstraksi Spirulina yaitu beta-karoten dapat diekstraksi dengan air dan dapat diaplikasikan pada krim kosmetik sebagai sumber antioksidan.
\end{abstract}

Kata kunci : Spirulina, Ekstraksi ultrasonikasi, Antioksidan

\begin{abstract}
EXTRACTION OF ANTIOXIDANT FROM Spirulina sp. BY ULTRASONICATION METHOD AND ITS APPLICATION IN COSMETICS CREAM. Spirulina sp. contains active substances as antioxidants that can be useful in industrial sector such as pharmacy, cosmetic, and food. Antioxidants can be obtained from extraction process. The aim of this reseach is to extract antioxidant from Spirulina by ultrasonication method and to apply it on cosmetic cream. The steps on this research are: extraction process by ultrasonication method with time variable of 15 minutes, 30 minutes, and 45 minutes, and solvent variable of water and ethanol; identification of antioxidant; analysis of antioxidant content; and application of extract on cream with concentration variable of $0.1 \%$ and $0.2 \%$; and sonication of cream with time variable of 15 and 30 minutes. The results showed the optimum of time sonication process was 15 minutes, with characteristic of antioxidant content, activities content, $\beta$-carotene content, and yield were $452.87 \mu \mathrm{M}, 70.27 \%, 15.98 \mathrm{mg} / \mathrm{kg}$ and $37.15 \%$, respectively. Furthermore, the results indicated that the optimum process of application extract on cream was achieved by 15 minutes sonication and $0.2 \%$ extract, with characteristic of $\beta$-carotene content $4.85 \mathrm{mg} / \mathrm{kg}$; antioxidant content $16.83 \mu \mathrm{M}$; cream were stable during cycling test; yellowish on colour, without odor, soft texture and homogen; $\mathrm{pH}$ 7; also have microorganism contamination below standard limit, therefore safe to be used. Extraction of Spirulina can be carried out by using water and the obtained beta $\beta$-caroten which can be applied on cream cosmetic as antioxidant source.
\end{abstract}

Keywords : Spirulina, Ultrasonication extraction, Antioxidant

PENDAHULUAN

Spirulina sp. termasuk salah satu jenis mikroalga yang bersifat autotrof, tidak memiliki inti sel sejati (prokariotik), uniselular dan berbentuk filament menyerupai spiral berwarna biru-hijau. Mikroalga ini merupakan salah satu sumber antioksidan dan pigmen alami yang 
aman digunakan sebagai zat aditif maupun dalam kosmetik (Nur 2014). Spirulina sp. mempunyai kandungan pigmen yang dapat berfungsi sebagai antioksidan, yaitu: klorofil, karoten, xantofil dan fikosianin (Sedjati et al. 2012). Terdapat dua mekanisme antioksidan, yaitu radikal bebas menangkap hidrogen dari antioksidan sehingga terbentuk kompleks antioksidan radikal yang stabil. Selanjutnya aktioksidan mendeaktivasi radikal bebas dengan transfer elektron tunggal, hal ini yang berpengaruh kestabilan larutan (Sadeli 2016). Antioksidan alami dapat menghambat atau mencegah terjadinya proses oksidasi oleh radikal bebas serta dapat menurunkan resiko kanker (Oktora, Ma'ruf, and Agustini 2016).

Senyawa antioksidan yang terkandung di dalam mikroalga sebagai pigmen adalah klorofil, karotenoid, dan fikobiliprotein (Fabrowska et al. 2015). Klorofil merupakan jenis pigmen yang terkandung hampir semua jenis mikroalga. Selain sebagai pigmen pada farmasi, senyawa turunan dari klorofil juga dapat digunakan sebagai produk kesehatan karena dapat menurunkan risiko terkena kanker (Nur 2014).

Sumber antioksidan dari pigmen yang lainnya adalah karotenoid dan fikosianin. Karotenoid adalah molekul lifofilik isoprenoid yang terdiri dari karoten (beta-karoten, alfakaroten, dan likopen) dan xantofil (lutein, astaxanthin, zeaxanthin, violaxanthin, loroxanthin, fukoxanthin). Pigmen kuning kemerahan beta-karoten dapat ditemukan pada beberapa spesies dari alga seperti Dunaliella Salina, Haemotococcus pluvialis, Spirulina dan Chorella. Spirulina juga mengakumulasi betakaroten lebih dari $0,8 \%-1,0 \%$ berat keringnya (Fretes et al. 2012). Fikosianin merupakan pigmen biru yang kebanyakan ditemui pada jenis Cyanobacteria, Rhodophyceae, dan Cryptophyceae. Fikosianin yang terkandung dalam 10 gram Spirulina kering adalah sebesar $1400 \mathrm{mg}$ (Rahmawati, Hidayatulloh, dan Suprayatmi 2017).

Bahan aktif antioksidan dari Spirulina didapatkan dengan cara ekstraksi. Ekstraksi dilakukan untuk memecahkan sel dengan metode antara lain secara kimia, mekanik dan enzimatik (Hosikian et al. 2010; Henriques, Silva, dan Rocha 2007). Beberapa faktor yang mempengaruhi ekstraksi mikroalga adalah jenis pelarut, suhu dan waktu proses (Plaza et al. 2009; lbañez et al. 2012). Pada umumnya proses ekstraksi mikroalga dilakukan dengan metode maserasi dan sistem soklet dengan menggunakan pelarut organik. Penggunaan pelarut organik, diperlukan proses pemurnian untuk menghilangkan residu pelarut yang terikut pada bahan aktif, karena pelarut ini tidak aman untuk kesehatan dan lingkungan. Pada proses tersebut diperlukan waktu yang lama dan suhu tinggi, yang akan mengakibatkan bahan aktif teroksidasi, sehingga mutu bahan aktif akan rendah (Kadam, Tiwari, dan O'Dennell 2013).

Pada penelitian ini digunakan jenis pelarut yang aman terhadap kesehatan, karena bahan aktif antioksidan akan digunakan untuk kosmetik dan farmasi. Kondisi suhu dan waktu proses yang digunakan adalah suhu rendah dan waktu proses ekstraksi lebih cepat. Salah satu metode ekstraksi yang dapat digunakan untuk melakukan proses tersebut adalah menggunakan metode ultrasonikasi, dimana pemecahan dinding sel dilakukan dengan menggunakan energi ultrasonik.

Ekstraksi Spirulina dengan menggunakan ultrasonikasi, menghasilkan ekstrak fikosianin sebesar 15,97\% pada frekuensi $42 \mathrm{kHz}$ dan $11,24 \%$ pada frekuensi $28 \mathrm{kHz}$. Ekstraksi menggunakan soklet menghasilkan esktrak fikosianin sebesar 11,24\%. Menggunakan ultrasonikasi dapat menurunkan waktu ekstraksi dari 4 jam menjadi 20 menit dan waktu optimum adalah $55{ }^{\circ} \mathrm{C}$ (Hadiyanto et al. 2016). Ekstraksi Spirulina menggunakan ultrasonikasi dengan variabel volume pelarut $(29 \mathrm{ml}, 40 \mathrm{ml}$ dan $60 \mathrm{ml}$ ) dan waktu ekstraksi (5 menit, 15 menit dan 25 menit) pada suhu $40{ }^{\circ} \mathrm{C}$ menghasilkan kondisi optimum frekuensi ultrasonikasi sebesar $40 \mathrm{kHz}$, waktu selama 25 menit, rasio biomassa:pelarut sebesar 1:6 dan yield sebesar 1,38 $\mu \mathrm{g} / \mathrm{ml}$ (Hadiyanto, Marsya, dan Fatkhiyatul 2015).

Ekstrak mikroalga Spirulina sp. dapat diformulasikan menjadi sediaan berbentuk krim antioksidan (Novak 2010). Krim merupakan sediaan setengah padat, berupa emulsi yang mengandung bahan dasar yang sesuai dan mengandung air tidak kurang dari 60\%. Sediaan krim untuk kulit dapat berfungsi sebagai pelindung yang baik untuk kulit dan penghantar antioksidan ke dalam kulit (Moldovan et al. 2017). Salah satu syarat yang harus dipenuhi suatu sediaan emulsi adalah stabil secara fisik karena tanpa hal itu, suatu emulsi akan menjadi dua fase yang terpisah. Kestabilan emulsi terlihat dari pemisahan fase (Dewi, Anwar, dan Yunita 2014).

Beta-karoten umumnya berasal dari turunan kelapa sawit (Crude Palm Oil) memiliki sifat tidak larut pada air dan larut pada lemak. Pada umumnya digunakan sebagai bahan pangan misalnya minyak goreng dan margarin yang berfungsi sebagai antioksidan. Nilai tambah antioksidan dari mikroalga dibandingkan dari kelapa sawit adalah karotenoid yang dihasilkan oleh mikroalga adalah jenis karotenoid primer, yang terdapat pada pigmen fotosintesis. Beta-karoten yang dihasilkan dari mikroalga Spirulina memiliki sifat larut pada air. Hal tersebut karena pada Cyanobacteria karotenoid membentuk Orange-CarotenoidProtein (OCP) yaitu karoten yang berikatan dengan gugus protein sehingga memungkinkannya untuk larut pada air (Kerfeld 2004). Sifat 
tersebut berguna untuk aplikasinya sebagai antioksidan dan pigmen di obat dan kosmetik. Nilai tambah lainnya adalah budidaya alga memiliki waktu singkat dan tidak terlalu dipengaruhi oleh iklim dan kondisi tanah jika dibandingkan dengan kelapa sawit. Proses ekstraksi beta-karoten dari mikroalga lebih mudah jika dibandingkan dengan kelapa sawit (proses hidrogenasi).

Berdasarkan pemaparan tersebut, maka dilakukan penelitian yang bertujuan untuk mengekstrak bahan aktif antioksidan Spirulina $s p$ dengan menggunakan metode ultrasonikasi dan pengeringan menggunakan freeze dryer, dan mengaplikasikannya pada krim kosmetik. Pada penelitian ini dilakukan uji coba serbuk ekstrak Spirulina dengan mengaplikasikannya pada krim kosmetik.

\section{BAHAN DAN METODE}

\section{Bahan}

Bahan penelitian ini adalah: mikroalga Spirulina sp. [Pusat Penelitian Bioteknologi dan Bioindustri Indonesia (PPBBI), Bogor], aquades, etanol [Merck], Red Virgin Palm Oil (RVPO) [PT. Nutri Palma Nabati, Bogor], asam stearat [Brataco], setil alkohol [Brataco], trietanolamin [Merck], propilen glikol [Brataco], dan gliserol [Brataco].

Peralatan yang digunakan dalam penelitian ini adalah: Hotplate stirrer [Selecta], neraca analitis [Mettler Toledo], sonikator [ChromTech], sentrifugasi [Kokusan], freeze dryer [Shimadzu], oven [Memmert], Spektrofotometer UV-VIS [Shimadzu], $\mathrm{pH}$ meter [Mettler Toledo], waterbath [Eyela], dan pengaduk [IKA].

\section{Metode \\ Proses Ekstraksi}

Proses ultrasonikasi dengan variabel waktu (15 menit, 30 menit dan 45 menit) dan pelarut (aquades, etanol 30\%, etanol $70 \%$ ) Tahapan proses adalah: 20 gram mikroalga dilarutkan dalam $100 \mathrm{ml}$ aquades atau etanol sampai terlarut sempurna, selanjutnya diultrasonikasi, untuk menjaga kestabilan suhu, maka selama proses dilakukan perendaman dengan air es. Selanjutnya, disentrifugasi dengan putaran 2500 rpm selama 30 menit, lalu dipisahkan antara endapan dan cairan. Cairan hasil ekstraksi selanjutnya di freeze dryer lalu dianalisa dan endapan dikeringkan.

\section{Identifikasi Jenis Antioksidan}

Ekstrak Spirulina sp. yang dihasilkan diukur panjang gelombangnya bedasarkan pada kisaran pigmen yang akan dideteksi secara kualitatif dengan spektrofotometri. Klorofil dideteksi pada kisaran panjang gelombang $300 \mathrm{~nm}-800 \mathrm{~nm}$. Beta-karoten dideteksi pada kisaran panjang gelombang $380 \mathrm{~nm}$ - $550 \mathrm{~nm}$. Fikosianin dideteksi pada kisaran panjang gelombang 400 nm - 700 nm. Puncak yang dihasilkan merupakan jenis pigmen yang terdapat pada ekstrak tersebut (Haryatfrehni et al. 2015).

\section{Analisa Kandungan Antioksidan}

Kandungan antioksidan dianalisa dengan metode Ascorbic acid Equivalent Antioxidant (AEAC). Kandungan antioksidan diukur dengan menentukan kapasitas senyawa radikal bebas dengan DPPH. Hasil ekstrak dicampurkan dengan larutan methanol DPPH. Campuran yang telah dihomogenisasi disimpan pada tempat yang gelap selama 120 menit dan absorbansinya diukur pada panjang gelombang 517 nm. Blanko menggunakan akuades. Hasil absorbansi direfleksikan terhadap kurva standar BHT untuk menentukan kandungan antioksidan $(\mu \mathrm{M})$ (Velde et al. 2013).

\section{Analisa Kadar Beta-Karoten}

Analisa beta-karoten dilakukan menggunakan HPLC mengacu pada penelitian yang telah dilakukan oleh Lioe, Warnasih, and Sutanto (2013).

\section{a. Preparasi larutan deret standard Beta- karoten}

Dipipet sebanyak 0,05 ml; 0,1 ml; 0,15 ml; $0,2 \mathrm{ml} ; 0,25 \mathrm{ml}$ standard beta-karoten $10 \mathrm{mg} / \mathrm{l}$ dan 0,05 ml; 0,1 ml; 0,25 ml; dan 0,5 ml standard induk beta-karoten $100 \mathrm{mg} / \mathrm{l}$, masingmasing dimasukkan dalam labu ukur $10 \mathrm{ml}$. Kemudian larutan tersebut diencerkan dengan fase gerak sampai tanda tera dan dihomogenkan. Kemudian disaring masingmasing larutan ke dalam vial amber $2 \mathrm{ml}$ dengan membrane filter GHP 0,45 $\mu \mathrm{m}$ dan diinjeksikan ke dalam HPLC.

\section{b. Preparasi larutan sampel}

Sampel ekstrak Spirulina padatan ditimbang $\pm 2 \mathrm{~g}$ ke dalam gelas piala $100 \mathrm{ml}$, ditambahkan $50 \mathrm{ml} \mathrm{KOH} \mathrm{10 \%} \mathrm{dan} \mathrm{dipanaskan}$ dengan waterbath pada suhu $80 \stackrel{\circ}{\circ}$ selama 30 menit. Kemudian didinginkan hingga suhu $40{ }^{\circ} \mathrm{C}$ dan dipindahkan ke dalam corong pisah $500 \mathrm{ml}$ serta dibilas menggunakan $10 \mathrm{ml}$ akuabides. Selanjutnya ditambahkan $25 \mathrm{ml}$ petroleum eter, diekstraksi selama 2 menit dengan shaker berkecepatan 120-150 rpm. Fase petroleum eter ditampung dalam labu kocok lainnya (larutan A), ekstraksi kembali fase air dengan $25 \mathrm{ml}$ petroleum eter sebanyak 2 kali ulangan. Fase petroleum eter ditampung kembali dalam larutan A dan dicuci menggunakan akuabides $50 \mathrm{ml}$ dan kocok selama 2 menit dengan shaker berkecpatan $120 \mathrm{rpm}$ - 150 rpm. Selanjutnya larutan diuapkan menggunakan Turbovap dengan 
suhu < 40 ํㅡ dan dilarukan menggunakan fase gerak ke dalam labu ukur $10 \mathrm{ml}$. Kemudian disaring menggunakan milipore 0,45 $\mu \mathrm{m}$ ke dalam vial amber $2 \mathrm{ml}$ dan diinjeksikan dalam HPLC.

\section{c. Kondisi kromatografi}

Kolom (Phenomenex, Luna C18(2) 110A, $4.00 \mathrm{~mm} \times 125 \mathrm{~mm}, 5 \mu \mathrm{m})$; fase gerak (Asetonitril:Isopropanol (65:35)); laju alir $(0,70 \mathrm{ml} / \mathrm{menit})$; volume injeksi $(20 \mu \mathrm{l})$; detector (PDA, Visible panjang gelombang $450 \mathrm{~nm}$ ); sampling rate (10 point/sec).

\section{d. Interpretasi hasil}

Perhitungan kadar beta-karoten dalam sampel dengan menggunakan kurva kalibrasi standard dengan persamaan garis: $\mathrm{Y}=\mathrm{bx}+\mathrm{a}$, dengan rumus sebagai berikut:

$$
\text { Kadar Beta-karoten }=\frac{\frac{(A s p l-a)}{b} \times V \times f p}{W}
$$

Keterangan:

A.spl : Luas area sampel

a : Intercept dari kurva kalibrasi standard

b : Slope dari kurva kalibrasi standard

Fp : Faktor pengenceran sampel

V : Volume labu akhir sampel (ml)

W : Bobot sampel (g)

\section{Proses Pembuatan Krim Kosmetik}

Bahan-bahan pembuatan base krim kosmetik dalam fase minyak meliputi Red Virgin Palm Oil (RVPO), asam stearat, setil alkohol, dan propilen glikol (fase 1) dicampurkan dalam beaker gelas lalu dipanaskan pada suhu $80^{\circ} \mathrm{C}$ hingga mencair dengan menggunakan waterbath sambil diaduk menggunakan mixer. Gliserol dilarutkan dalam aquades yang telah dipanaskan pada suhu $80^{\circ} \mathrm{C}$ sambil diaduk. Campuran fase air tersebut diaduk hingga larut sempurna menggunakan alat mixer. Selanjutnya fase minyak ditambahkan ke fase air sambil diaduk dengan kecepatan 300 rpm. Kemudian ditambahkan trietanolamin sebagai bahan emulsi sambil terus diaduk hingga larut sempurna. Base kosmetik selanjutnya ditambahkan ekstrak mikroalga dan disonikasi. Formulasi pembuatan krim kosmetik dapat dilihat pada Tabel 1. Variabel pembuatan krim adalah pada jumlah ekstrak Spirulina dan durasi waktu sonikasi. Pada formula a, tidak dilakukan sonikasi. Formula b, c, dan d disonikasi selama 15 menit, sedangkan formula e dan f disonikasi selama 30 menit.

Evaluasi Fisik Krim (Dewi, Anwar, dan Yunita 2014).

a) Analisis pengukuran $\mathrm{pH}$ menggunakan $\mathrm{pH}$ meter yang dikalibrasi terlebih dahulu menggunakan larutan dasar $\mathrm{pH} 4$ dan $\mathrm{pH} 7$ sebelum mengukur $\mathrm{pH}$ krim

b) Viskositas dan sifat alir dilakukan menggunakan viskometer Brookfield dan menggunakan spindel no. 6 krim dimasukkan ke dalam wadah gelas kemudian spindel yang telah dipasang diturunkan sehingga batas spindel tercelup ke dalam krim. Kecepatan alat dipasang pada 2 rpm, 4 rpm, 10 rpm, 20 rpm; lalu dibalik 10 rpm, 4 rpm, 2 rpm; secara berturur-turut, kemudian dibaca dan dicatat skalanya (dialreading) ketika jarum merah yang bergerak telah stabil. Nilai viskositas ( $\mathrm{n}$ ) dalam centipoise (cps) diperoleh dari hasil perkalian dialreading dengan faktor koreksi khusus untuk masingmasing spindel.

c) Analisis organoleptis merupakan pengujian yang didasarkan pada proses penginderaan. Pengujian organoleptis ini bertujuan untuk melihat kestabilan fisik dari sediaan krim yang dibuat dengan melihat perubahan tekstur, warna dan bau selama waktu penyimpanan. Pengamatan dilakukan setelah penyimpanan pada suhu kamar pada minggu ke-1 hingga minggu ke-8.

d) Cycling test dilakukan dengan cara sampel krim disimpan pada suhu $4^{\circ} \mathrm{C}$ selama 24 jam lalu dipindahkan ke dalam oven bersuhu $40^{\circ} \pm 2^{\circ} \mathrm{C}$ selama 24 jam (satu siklus). Uji dilakukan sebanyak 6 siklus, kemudian diamati perubahan fisik yang terjadi (apakah ada pemisahan).

Tabel 1. Formulasi krim kosmetik

\begin{tabular}{lllllll}
\hline \multicolumn{1}{c}{ Bahan } & \multicolumn{5}{c}{ Formula $(\%)$} \\
\cline { 2 - 7 } & $\mathrm{a}$ & $\mathrm{b}$ & $\mathrm{c}$ & $\mathrm{d}$ & $\mathrm{e}$ & $\mathrm{f}$ \\
\hline Red Virgin Palm Oil (RVPO) & 1,5 & 1,5 & 1,5 & 1,5 & 1,5 & 1,5 \\
\hline Asam stearate & 5 & 5 & 5 & 5 & 5 & 5 \\
\hline Setil alcohol & 3 & 3 & 3 & 3 & 3 & 3 \\
\hline Trietanolamin & 0,4 & 0,4 & 0,4 & 0,4 & 0,4 & 0,4 \\
\hline Propilen glikol & 8 & 8 & 8 & 8 & 8 & 8 \\
\hline Gliserol & 2 & 2 & 2 & 2 & 2 & 2 \\
\hline Akuades & 80,1 & 80,1 & 80,1 & 80,1 & 80,1 & 80,1 \\
\hline Ekstrak Spirulina & 0 & 0 & 0.1 & 0.2 & 0.1 & 0.2 \\
\hline
\end{tabular}




\section{Analisa Cemaran Mikroba}

Analisa cemaran mikroba ALT, kapang dan khamir mengacu pada metode SNI (Standar Nasional Indonesia (SNI) 16-4399-1996 1996)

\section{HASIL DAN PEMBAHASAN}

Mikroalga Spirulina sp. mengandung banyak senyawa protein, antioksidan dan mineral. Senyawa protein berguna untuk pertumbuhan dan perbaikan sel-sel di dalam tubuh manusia. Kadar protein Spirulina yaitu $62,4 \%$. Spirulina juga mengandung senyawa antioksidan berupa beta-karoten sebanyak 396 $\mathrm{mg} / 100$ gram dan vitamin E sebanyak 12,7 $\mathrm{mg} / 100$ gram. Senyawa antioksidan berguna untuk menangkal radikal bebas yang berasal dari pangan dan lingkungan. Menurut Sayuti dan Yenrina (2015), radikal bebas adalah molekul yang kehilangan elektron, sehingga molekul tersebut menjadi tidak stabil dan selalu berusaha mengambil elektron dari molekul lain atau sel lain. Berdasarkan karakteristiknya mikroalga Spirulina berpotensi sebagai bahan baku sumber senyawa antioksidan yang dapat digunakan untuk bahan kosmetik dan farmasi.

Ekstraksi Spirulina dengan proses utrasonikasi dilakukan dengan beberapa variable yaitu suhu dan pelarut. Hal ini bertujuan untuk menentukan suhu, waktu dan pelarut yang optimal untuk mendapatkan antioksidan dan inhibisi yang tinggi. Pada metode ultrasonikasi, gelombang ultrasonik digunakan untuk membuat gelembung kavitasi pada larutan. Gelembung akan pecah dan menyebabkan terbentuknya gelombang kejut dan pancaran cairan sehingga menyebabkan dinding sel pecah. Pecahnya dinding sel akan menyebabkan komponen di dalam sel keluar bercampur dengan larutan. Keuntungan menggunakan ekstraksi metode ultrasonikasi adalah meningkatkan yield ekstraksi dengan waktu proses lebih singkat (Soares et al. 2016). Selanjutnya hasil ekstraksi Spirulina dikeringkan menjadi padatan untuk mempermudah penyimpanan dan pengggunaannya (Gambar 1). Proses untuk membuat ekstrak mikroalga dari cairan menjadi padatan, dilakukan dengan alat freeze dryer. Proses freeze drying adalah proses pengeringan bahan aktif dari tumbuh-tumbuhan dengan menggunakan panas rendah, sehingga tidak merusak antioksidan di dalam bahan aktif tersebut. Ekstrak Spirulina dari proses ultrasonikasi dengan pelarut air, memiliki kandungan antioksidan yang tinggi, selanjutnya dilakukan proses freeze drying. Rendemen serbuk antioksidan hasil freeze drying didapatkan rata-rata sebesar $37,15 \mathrm{gram} / \mathrm{L}$.

\section{Identifikasi Jenis Antioksidan}

Hasil indentifikasi ekstrak Spirulina menunjukkan terdapat tiga jenis pigmen yaitu beta-karoten (bagian dari karotenoid), klorofil dan fikosianin (bagian dari fikobiliprotein) dapat dilihat pada Gambar 2. Pada masing-masing pigmen tersebut, mempunyai panjang gelombang yang berbeda. Ekstrak Spirulina (cairan) dibandingkan panjang gelombangnya klorofil, beta-karoten dan fikosianin. Klorofil dideteksi pada kisaran panjang gelombang $300 \mathrm{~nm}$ - $800 \mathrm{~nm}$, dengan beberapa puncak absorbansi yaitu puncak absorbansi pada $400 \mathrm{~nm}-475 \mathrm{~nm}$ yang merupakan klorofil a dan b; dan puncak absorbansi pada panjang gelombang di kisaran $690 \mathrm{~nm}$ yang merupakan klorofil d. Hasil tersebut sesuai dengan penelitian yang dilakukan oleh Haryatfrehni et al. (2015) yaitu hasil pembacaan spektrofotometri absorbansi puncak dari klorofil a dan b berada di kisaran $400 \mathrm{~nm}$ - $475 \mathrm{~nm}$ dan klorofil d pada kisaran $690 \mathrm{~nm}$.

Identifikasi beta-karoten dideteksi pada kisaran panjang gelombang $380 \mathrm{~nm}-550 \mathrm{~nm}$ dengan puncak absorbansi pada kisaran $400 \mathrm{~nm}$ sampai dengan $470 \mathrm{~nm}$. Identifikasi pigmen fikobiliprotein dilakukan dengan mengukur spektrum pigmen fikobiliprotein pada panjang gelombang $300 \mathrm{~nm}$ sampai dengan $700 \mathrm{~nm}$ (Agustini 2007). Pada penelitian ini fikosianin dideteksi pada kisaran panjang gelombang $400 \mathrm{~nm}-700 \mathrm{~nm}$, dengan puncak absorbansi pada panjang gelombang kisaran $600 \mathrm{~nm}$ sampai dengan $700 \mathrm{~nm}$. Pada penggunaan pelarut air dan etanol hanya terdeteksi puncak di kisaran panjang gelombang $600 \mathrm{~nm}-700 \mathrm{~nm}$ yang merupakan fikosianin, tidak ditemukan adanya fikoeritrin dengan puncak pada panjang gelombang $560 \mathrm{~nm}$ - 577 nm (Dumay dan Morançais 2016).

Perbedaan penggunaan pelarut etanol dan air, secara keseluruhan dengan pengamatan deskriptif tidak memberikan range puncak yang berbeda secara signifikan. Perbedaan terlihat pada absorbansi pigmen. Pada etanol, absorbansi pigmen relatif lebih besar dibandingkan dengan air.
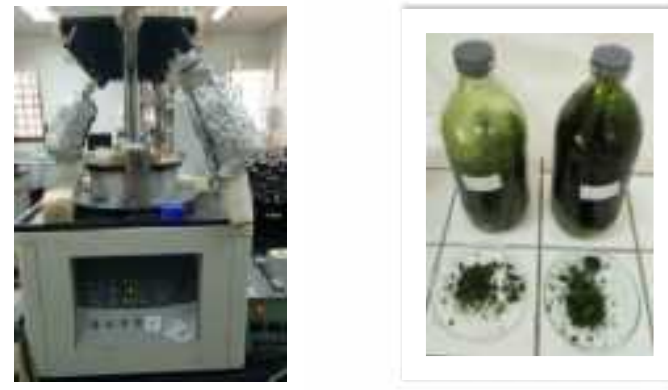

Gambar 1. Proses dan hasil freeze drying ekstrak Spirulina 


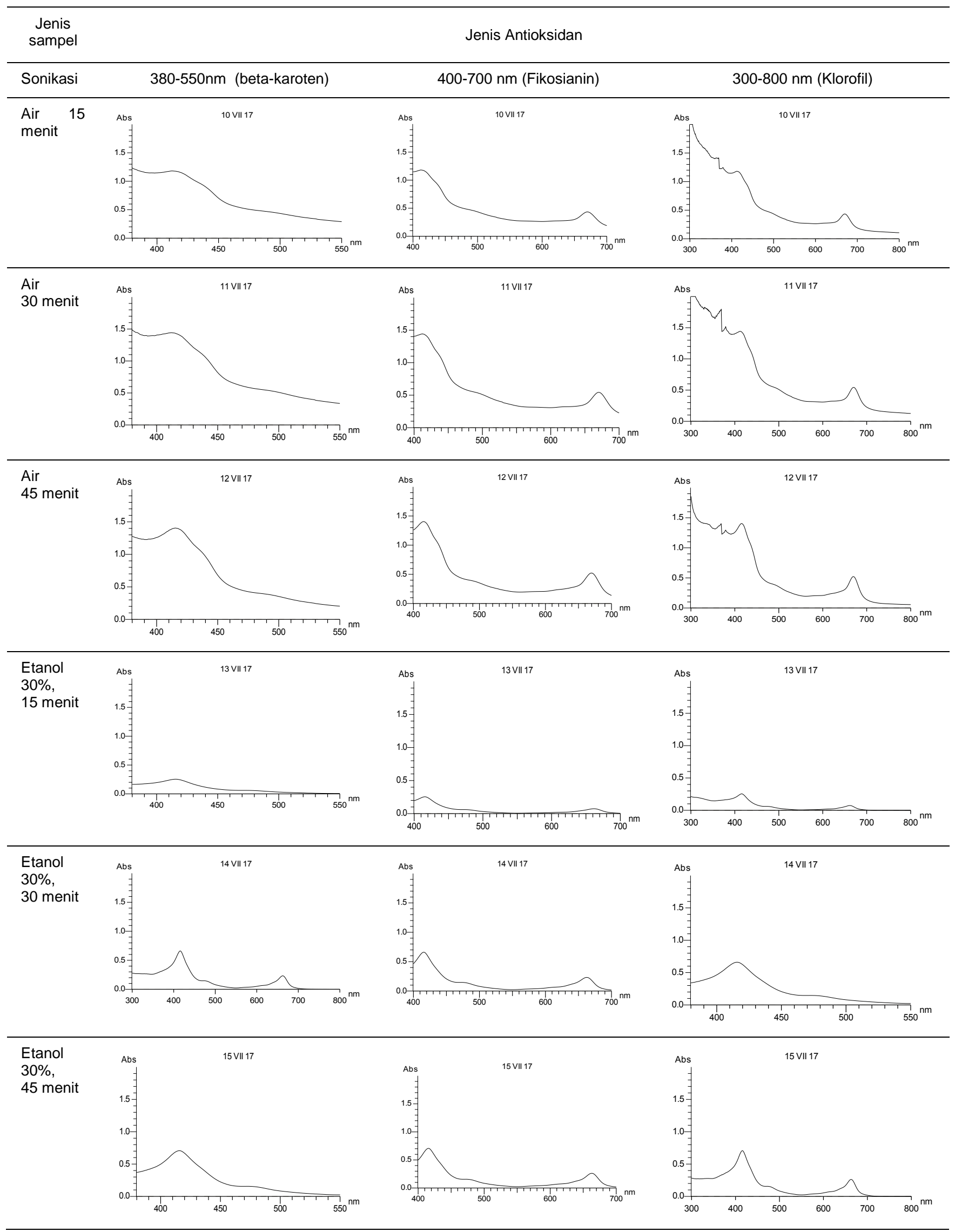

Gambar 2. Identifikasi jenis antioksidan dengan menggunakan spektrofotometer 
Pelarut saat ekstraksi berperan penting untuk ekstraksi pada jenis atau sifat pigmen yang akan diekstraksi. Hal tersebut dapat dikarenakan fikosianin merupakan pigmen yang larut pada air. Klorofil memiliki dua bagian yaitu bagian macrocycle (gugus cincin siklopentaton dan gugus propionic ester) yang hidrofilik dan gugus phytol yang hidrofobik, sehingga klorofil merupakan pigmen yang dapat terlarut pada air (Queiroz et al. 2017).

Karotenoid memiliki kumpulan gugus yang bervariatif (beta-karoten, alfa karoten, dan likopen, lutein, astaxanthin, zeaxanthin, violaxanthin, loroxanthin, fukoxanthin). Secara umum karotene merupakan kandungan yang terlarut pada lemak, namun karoten juga dapat berikatan dengan protein membentuk ikatan pigmen-protein, sehingga memiliki sifat yang dapat larut pada air. Pelarut berperan untuk memudahkan permeabilitas dinding sel mikroalga sehingga memudahkan pigmen untuk larut pada pelarut, sehingga meningkatkan yield pigmen yang terekstrak (Henriques, Silva, dan Rocha 2007).

\section{Kandungan Antioksidan Hasil Ekstraksi Spirulina}

Hasil ekstraksi mikroalga dengan menggunakan ekstraksi ultrasonikasi, selanjutnya dianalisa kandungan antioksidan dengan standar pembanding yang digunakan adalah Butylated Hydroxy Toluene (BHT).

Kandungan antioksidan dalam Spirulina pada Tabel 2 menunjukkan bahwa kondisi proses yang menghasilkan kadar antioksidan tertinggi adalah proses ultrasonikasi menggunakan pelarut air dan waktu sonikasi 15 menit yaitu 452,87 $\mu \mathrm{M}$. Pada kondisi proses menggunakan pelarut air dengan waktu sonikasi 45 menit tidak menghasilkan antioksidan, hal ini disebabkan karena proses ultrasonikasi merupakan proses eksoterm atau proses yang menghasilkan panas, antioksidan akan menurun disebabkan suhu yang tinggi. Menurut Hadiyanto et al. (2016) peningkatan ekstraksi lebih dari 60 -C dapat mengakibatkan denaturasi protein yang mengakibatkan turunnya kadar antioksidan Proses ekstraksi menggunakan pelarut etanol $30 \%$ dan $70 \%$ juga tidak menghasilkan antioksidan, hal ini disebabkan jenis pelarut etanol terlalu jenuh sehingga antioksidannya teroksidasi.

\section{Kandungan Antioksidan Beta-Karoten}

Kandungan beta-karoten pada ekstrak Spirulina dapat dilihat pada Tabel 3. Hasil analisa menunjukkan bahwa makin lama waktu ultrasonikasi akan menghasilkan kadar betakaroten semakin tinggi. Hal ini disebabkan makin lama waktu ultrasonikasi, maka akan semakin tinggi suhu ekstraksi mikroalga. Durasi ultrasonikasi yang lama akan memperbanyak sel hingga tilakoid yang pecah, karoten yang berada di tilakoid akan keluar dan tercampur di air. Proses sonikasi merupakan proses eksoterm yang menghasilkan panas dan dapat menciptakan pergerakan antarmuka antara padat dan cair, sehingga menyebabkan peningkatan laju transfer massa dan meningkatkan yield produk. Ekstraksi menggunakan metode ini dapat menghasilkan $50 \%$ yield lebih tinggi dibandingkan metode ekstraksi konvensional (Hadiyanto, Marsya, dan Fatkhiyatul 2015). Pada Tabel 3 menunjukkan ekstrak Spirulina mengandung antioksidan sebagai beta-karoten yang tertinggi didapat dari proses ultrasonikasi dengan waktu ekstraksi selama 45 menit yaitu sebesar 22,67 mg/kg.

Kandungan antioksidan tidak selaras dengan kandungan beta-karoten, pada waktu sonikasinya, hal tersebut dikarenakan antioksidan terdiri dari beberapa komponen selain beta-karoten.

Tabel 2. Kandungan antioksidan dalam ekstrak mikroalga Spirulina berdasarkan kondisi sonikasi

\begin{tabular}{ccccc}
\hline No & Jenis pelarut & Waktu sonikasi (menit) & $\begin{array}{c}\text { Suhu } \\
\left({ }^{\circ} \mathrm{C}\right)\end{array}$ & $\begin{array}{c}\text { Kandungan antioksidan } \\
(\mu \mathrm{M})\end{array}$ \\
\hline 1 & Air & 15 & 35 & 452,87 \\
2 & Air & 30 & 50 & 283,53 \\
3 & Air & 45 & 60 & $>15,625$ \\
4 & Etanol 30\% & 15 & 317,53 \\
5 & Etanol 30\% & 30 & 50 & $>15,625$ \\
6 & Etanol 30\% & 45 & 70 & $>15,625$ \\
7 & Etanol 70\% & 15 & 35 & $>15,625$ \\
8 & Etanol 70\% & 30 & 50 & $>15,625$ \\
9 & Etanol 70\% & 45 & 60 & $>15,625$ \\
\hline Ket : $>15,625=$ tidak terdeteksi adanya kandungan antioksidan & &
\end{tabular}


Tabel 3. Hasil analisa kadar beta-karoten pada ekstrak Spirulina

\begin{tabular}{cc}
\hline $\begin{array}{c}\text { Waktu sonikasi } \\
\text { (menit) }\end{array}$ & Kadar beta-karoten $(\mathrm{mg} / \mathrm{kg})$ \\
\hline 15 & 15,08 \\
30 & 21,77 \\
45 & 22,67 \\
\hline
\end{tabular}

\section{Aplikasi Ekstrak Spirulina Pada Krim Kosmetik}

Hasil ekstrak Spirulina berbentuk serbuk diaplikasikan pada pembuatan krim kosmetik. Variasi formula krim kosmetik yang dibuat dapat dilihat pada Gambar 3. Penambahan bahan esktrak Spirulina bertujuan sebagai bahan antioksidan alami, karena pigmennya yang mengandung antioksidan alami (Nur 2014; Sedjati et al. 2012). Menurut Gianeti dan Maia Campos (2014) aplikasi zat antioksidan aktif dalam formulasi kosmetik untuk melindungi kulit terhadap kerusakan oksidatif oleh radiasi UV dan mencegah tanda-tanda penuaan.

Salah satu antioksidan yang terkandung di dalam Spirulina adalah beta-karoten. Krim kosmetik yang ditambahkan ekstrak mikroalga dilakukan analisa kadar beta-karoten dan kadar antioksidan (Tabel 4). Berdasarkan Tabel 4. menunjukkan bahwa semakin lama proses sonikasi maka kadar beta-karoten dan kadar antioksidan akan semakin menurun. Hal tersebut menunjukkan bahwa makin lama waktu sonikasi akan mengakibatkan beta-karoten dan antioksidan teroksidasi, yang disebabkan oleh proses eksotermis dari proses sonikasi (Hadiyanto, Marsya, dan Fatkhiyatul 2015). Krim yang mengandung antioksidan sangat sensitif terhadap cahaya dan suhu (Chaiyasut et al.

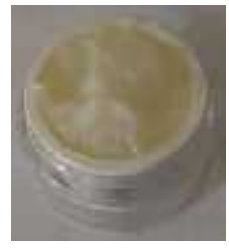

a

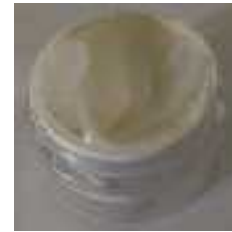

b

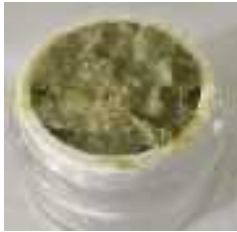

C

2018). Pada penelitian ini, krim yang mengandung beta-karoten sebagai antioksidan yang terbaik dihasilkan oleh proses sonikasi selama 15 menit dengan penambahan ekstrak Spirulina 0,2\% yaitu sebesar 4,85 mg/kg. Krim yang menghasilkan antioksidan tertinggi didapatkan pada krim dengan penambahan ekstrak Spirulina 0,1\% dengan proses sonikasi 15 menit.

Krim kosmetik dilakukan beberapa analisa, diantaranya $\mathrm{pH}$, viskositas dan cemaran mikroba yang dapat dilihat pada Tabel 5. Nilai $\mathrm{pH}$ krim kosmetik masih berada dalam kisaran $\mathrm{pH}$ krim normal. Menurut Standar Nasional Indonesia (SNI) 16-4399-1996 (1996), pH krim adalah sesuai dengan $\mathrm{pH}$ kulit, yaitu berkisar 4,5 - 8,0. Jika pH krim tidak sesuai dengan $\mathrm{pH}$ kulit maka akan menyebabkan iritasi kulit. Menurut Peraturan Badan Pengawas Obat dan Makanan Republik Indonesia (2014) tentang Perubahan atas Peraturan BPOM Nomor HK. 03.1.23.07.11.6662 tahun 2011, batas cemaran mikroba Angka Lempeng Total (ALT) yaitu tidak lebih dari $10^{3}$ koloni/g. Sedangkan Angka Kapang Khamir (AKK) yaitu tidak lebih dari $10^{3}$ koloni/g. Sehingga berdasarkan analisa cemaran mikroba (Tabel 5) dapat disimpulkan krim dengan komposisi di atas aman untuk digunakan.

Tabel 4. Hasil analisa beta-karoten krim kosmetik

\begin{tabular}{ccc}
\hline $\begin{array}{c}\text { Formula krim } \\
\text { kosmetik }\end{array}$ & $\begin{array}{c}\text { Kadar beta- } \\
\text { karoten } \\
(\mathrm{mg} / \mathrm{kg})\end{array}$ & $\begin{array}{c}\text { Kandungan } \\
\text { antioksidan } \\
(\mu \mathrm{M})\end{array}$ \\
\hline c & 3,49 & 24,33 \\
d & 4,85 & 16,83 \\
e & 3,18 & 11,83 \\
$\mathrm{f}$ & 4,04 & 5,17 \\
\hline
\end{tabular}

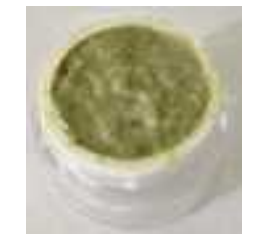

d

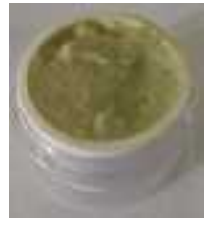

e

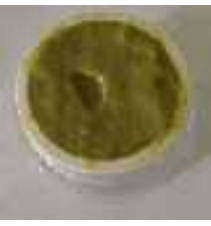

f

Gambar. 3 Variasi formula krim yang dibuat pada penelitian : a) krim tanpa ekstrak Spirulina dan tanpa perlakuan sonikasi; b) krim tanpa ekstrak Spirulina dengan perlakuan sonikasi 15 menit; c) krim dengan penambahan ekstrak Spirulina $0,1 \mathrm{~g}$ dan sonikasi 15 menit; d) krim dengan penambahan ekstrak Spirulina 0,2 g dan sonikasi 15 menit; e) krim dengan penambahan ekstrak Spirulina 0,1 g dan sonikasi 30 menit; f) krim dengan penambahan ekstrak Spirulina 0,2 g dan sonikasi 30 menit.

Tabel 5. Hasil analisa krim kosmetik

\begin{tabular}{lcccccc}
\hline \multicolumn{1}{c}{ Jenis analisa } & \multicolumn{7}{c}{ Formula krim } \\
\cline { 2 - 7 } & $\mathrm{a}$ & $\mathrm{b}$ & $\mathrm{c}$ & $\mathrm{d}$ & $\mathrm{e}$ & $\mathrm{f}$ \\
\hline $\mathrm{pH}$ & 7 & 7 & 7 & 7 & 7 & 7 \\
Vikositas pada suhu $50^{\circ} \mathrm{C}(\mathrm{cps})$ & 80 & 80 & 80 & 80 & 80 & 80 \\
$\mathrm{ALT}(\mathrm{kol} / \mathrm{g})$ & $6,8 \times 10^{2}$ & $7,2 \times 10^{2}$ & $3,6 \times 10^{2}$ & $2,8 \times 10^{2}$ & $3,8 \times 10^{2}$ & $7,4 \times 10^{2}$ \\
Angka Kapang (kol/g) & $<10$ & $<10$ & $<10$ & $<10$ & $<10$ & $<10$ \\
Angka Khamir (kol/g) & $<10$ & $<10$ & $<10$ & $<10$ & $<10$ & $<10$ \\
\hline
\end{tabular}


Evaluasi krim kosmetik juga dapat dilakukan pengamatan organoleptis (Tabel 6). Secara visual dapat dilihat bahwa krim dengan penambahan ekstrak Spirulina berwarna kuning kehijauan karena ekstrak Spirulina berwarna hijau. Warna krim kosmetik hingga minggu ke-8 stabil/tidak terjadi perubahan. Aroma krim tidak berbau tengik hingga minggu ke-8. Hal ini menunjukkan bahwa fase minyak dalam krim tidak mengalami oksidasi. Perubahan warna dan bau disebabkan oleh oksigen dari udara yang mengoksidasi fase lemak atau minyak, selain itu cahaya juga dapat menimbulkan reaksi oksidasi (Dewi, Anwar, dan Yunita 2014; Wulandari 2016). Krim kosmetik selama 8 minggu homogen, sehingga dapat disimpulkan bahwa secara keseluruhan krim kosmetik stabil. Krim dengan perlakuan sonikasi memiliki tekstur yang lebih lembut dibandingkan dengan tanpa sonikasi. Hal ini disebabkan karena proses ultrasonikasi pada pembuatan krim kosmetik dapat memperkecil ukuran krim hingga mencapai ukuran nano, sehingga tekstur krim menjadi lebih lembut (Rahmi et al. 2014).

Tabel 6. Hasil pengamatan organoleptis krim kosmetik

\begin{tabular}{|c|c|c|c|c|c|c|c|c|c|}
\hline \multirow{2}{*}{$\begin{array}{c}\text { Formula } \\
\text { krim }\end{array}$} & \multirow{2}{*}{ Kondisi } & \multicolumn{8}{|c|}{ Minggu ke- } \\
\hline & & 1 & 2 & 3 & 4 & 5 & 6 & 7 & 8 \\
\hline \multirow{4}{*}{ a } & Warna & kuning & kuning & kuning & kuning & kuning & kuning & kuning & kuning \\
\hline & Bau & $\begin{array}{c}\text { tidak } \\
\text { berbau }\end{array}$ & $\begin{array}{c}\text { tidak } \\
\text { berbau }\end{array}$ & $\begin{array}{c}\text { tidak } \\
\text { berbau }\end{array}$ & $\begin{array}{c}\text { tidak } \\
\text { berbau }\end{array}$ & $\begin{array}{c}\text { tidak } \\
\text { berbau }\end{array}$ & $\begin{array}{c}\text { tidak } \\
\text { berbau }\end{array}$ & $\begin{array}{c}\text { tidak } \\
\text { berbau }\end{array}$ & $\begin{array}{c}\text { tidak } \\
\text { berbau }\end{array}$ \\
\hline & Tekstur & halus & halus & halus & halus & halus & Halus & halus & halus \\
\hline & Homogenitas & homogen & homogen & homogen & homogen & homogen & Homogen & homogen & homogen \\
\hline \multirow{4}{*}{$b$} & Warna & $\begin{array}{l}\text { kuning } \\
\text { pucat }\end{array}$ & $\begin{array}{l}\text { kuning } \\
\text { pucat }\end{array}$ & $\begin{array}{l}\text { kuning } \\
\text { pucat }\end{array}$ & $\begin{array}{l}\text { kuning } \\
\text { pucat }\end{array}$ & $\begin{array}{l}\text { kuning } \\
\text { pucat }\end{array}$ & $\begin{array}{l}\text { kuning } \\
\text { pucat }\end{array}$ & $\begin{array}{l}\text { kuning } \\
\text { pucat }\end{array}$ & $\begin{array}{l}\text { kuning } \\
\text { pucat }\end{array}$ \\
\hline & Bau & $\begin{array}{c}\text { tidak } \\
\text { berbau }\end{array}$ & $\begin{array}{c}\text { tidak } \\
\text { berbau }\end{array}$ & $\begin{array}{c}\text { tidak } \\
\text { berbau }\end{array}$ & $\begin{array}{c}\text { tidak } \\
\text { berbau }\end{array}$ & $\begin{array}{c}\text { tidak } \\
\text { berbau }\end{array}$ & $\begin{array}{c}\text { tidak } \\
\text { berbau }\end{array}$ & $\begin{array}{c}\text { tidak } \\
\text { berbau }\end{array}$ & $\begin{array}{c}\text { tidak } \\
\text { berbau }\end{array}$ \\
\hline & Tekstur & $\begin{array}{l}\text { halus, } \\
\text { lembut }\end{array}$ & halus & halus & halus & halus & halus & halus & halus \\
\hline & Homogenitas & homogen & homogen & homogen & homogen & homogen & homogen & homogen & homogen \\
\hline \multirow{4}{*}{ c } & Warna & $\begin{array}{c}\text { kuning } \\
\text { kehijauan }\end{array}$ & $\begin{array}{c}\text { kuning } \\
\text { kehijauan }\end{array}$ & $\begin{array}{c}\text { kuning } \\
\text { kehijauan }\end{array}$ & $\begin{array}{l}\text { kuning } \\
\text { kehijauan }\end{array}$ & $\begin{array}{l}\text { kuning } \\
\text { kehijauan }\end{array}$ & $\begin{array}{l}\text { kuning } \\
\text { kehijauan }\end{array}$ & $\begin{array}{l}\text { kuning } \\
\text { kehijauan }\end{array}$ & $\begin{array}{l}\text { kuning } \\
\text { kehijauan }\end{array}$ \\
\hline & Bau & $\begin{array}{c}\text { tidak } \\
\text { berbau }\end{array}$ & $\begin{array}{c}\text { tidak } \\
\text { berbau }\end{array}$ & $\begin{array}{c}\text { tidak } \\
\text { berbau }\end{array}$ & $\begin{array}{c}\text { tidak } \\
\text { berbau }\end{array}$ & $\begin{array}{c}\text { tidak } \\
\text { berbau }\end{array}$ & $\begin{array}{c}\text { tidak } \\
\text { berbau }\end{array}$ & $\begin{array}{c}\text { tidak } \\
\text { berbau }\end{array}$ & $\begin{array}{c}\text { tidak } \\
\text { berbau }\end{array}$ \\
\hline & Tekstur & $\begin{array}{l}\text { halus, } \\
\text { lembut }\end{array}$ & halus & halus & halus & halus & Halus & halus & halus \\
\hline & Homogenitas & homogen & homogen & homogen & homogen & homogen & homogen & homogen & homogen \\
\hline \multirow{4}{*}{$d$} & Warna & $\begin{array}{c}\text { kuning } \\
\text { kehijauan }\end{array}$ & $\begin{array}{c}\text { kuning } \\
\text { kehijauan }\end{array}$ & $\begin{array}{c}\text { kuning } \\
\text { kehijauan }\end{array}$ & $\begin{array}{c}\text { kuning } \\
\text { kehijauan }\end{array}$ & $\begin{array}{c}\text { kuning } \\
\text { kehijauan }\end{array}$ & $\begin{array}{c}\text { kuning } \\
\text { kehijauan }\end{array}$ & $\begin{array}{c}\text { kuning } \\
\text { kehijauan }\end{array}$ & $\begin{array}{c}\text { kuning } \\
\text { kehijauan }\end{array}$ \\
\hline & Bau & $\begin{array}{c}\text { tidak } \\
\text { berbau }\end{array}$ & $\begin{array}{c}\text { tidak } \\
\text { berbau }\end{array}$ & $\begin{array}{c}\text { tidak } \\
\text { berbau }\end{array}$ & $\begin{array}{c}\text { tidak } \\
\text { berbau }\end{array}$ & $\begin{array}{c}\text { tidak } \\
\text { berbau }\end{array}$ & $\begin{array}{c}\text { tidak } \\
\text { berbau }\end{array}$ & $\begin{array}{c}\text { tidak } \\
\text { berbau }\end{array}$ & $\begin{array}{c}\text { tidak } \\
\text { berbau }\end{array}$ \\
\hline & Tekstur & $\begin{array}{l}\text { halus, } \\
\text { lembut }\end{array}$ & halus & halus & halus & halus & halus & halus & halus \\
\hline & Homogenitas & homogen & homogen & homogen & homogen & homogen & homogen & homogen & homogen \\
\hline \multirow{4}{*}{ e } & Warna & $\begin{array}{l}\text { kuning } \\
\text { kehijauan }\end{array}$ & $\begin{array}{l}\text { kuning } \\
\text { kehijauan }\end{array}$ & $\begin{array}{l}\text { kuning } \\
\text { kehijauan }\end{array}$ & $\begin{array}{l}\text { kuning } \\
\text { kehijauan }\end{array}$ & $\begin{array}{l}\text { kuning } \\
\text { kehijauan }\end{array}$ & $\begin{array}{l}\text { kuning } \\
\text { kehijauan }\end{array}$ & $\begin{array}{l}\text { kuning } \\
\text { kehijauan }\end{array}$ & $\begin{array}{l}\text { kuning } \\
\text { kehijauan }\end{array}$ \\
\hline & Bau & $\begin{array}{c}\text { tidak } \\
\text { berbau }\end{array}$ & $\begin{array}{c}\text { tidak } \\
\text { berbau }\end{array}$ & $\begin{array}{c}\text { tidak } \\
\text { berbau }\end{array}$ & $\begin{array}{c}\text { tidak } \\
\text { berbau }\end{array}$ & $\begin{array}{c}\text { tidak } \\
\text { berbau }\end{array}$ & $\begin{array}{c}\text { tidak } \\
\text { berbau }\end{array}$ & $\begin{array}{l}\text { tidak } \\
\text { berbau }\end{array}$ & $\begin{array}{c}\text { tidak } \\
\text { berbau }\end{array}$ \\
\hline & Tekstur & $\begin{array}{l}\text { halus, } \\
\text { lembut }\end{array}$ & halus & halus & halus & halus & halus & halus & halus \\
\hline & Homogenitas & homogen & homogen & homogen & homogen & homogen & Homogen & homogen & homogen \\
\hline \multirow{4}{*}{$f$} & Warna & Hijau & Hijau & Hijau & Hijau & Hijau & Hijau & Hijau & Hijau \\
\hline & Bau & $\begin{array}{c}\text { tidak } \\
\text { berbau }\end{array}$ & $\begin{array}{c}\text { tidak } \\
\text { berbau }\end{array}$ & $\begin{array}{c}\text { tidak } \\
\text { berbau }\end{array}$ & $\begin{array}{c}\text { tidak } \\
\text { berbau }\end{array}$ & $\begin{array}{c}\text { tidak } \\
\text { berbau }\end{array}$ & $\begin{array}{c}\text { tidak } \\
\text { berbau }\end{array}$ & $\begin{array}{c}\text { tidak } \\
\text { berbau }\end{array}$ & $\begin{array}{c}\text { tidak } \\
\text { berbau }\end{array}$ \\
\hline & Tekstur & $\begin{array}{l}\text { halus, } \\
\text { lembut }\end{array}$ & halus & halus & halus & halus & halus & halus & halus \\
\hline & Homogenitas & homogen & homogen & homogen & homogen & homogen & homogen & homogen & homogen \\
\hline
\end{tabular}


Tabel. 7. Hasil kestabilan cycling test krim kosmetik

\begin{tabular}{ccc}
\hline Formula krim & Siklus ke-0 & Siklus ke-12 \\
\hline a & Stabil (Tidak terjadi pemisahan fase) & Stabil (Tidak terjadi pemisahan fase) \\
b & Stabil (Tidak terjadi pemisahan fase) & Stabil (Tidak terjadi pemisahan fase) \\
c & Stabil (Tidak terjadi pemisahan fase) & Stabil (Tidak terjadi pemisahan fase) \\
d & Stabil (Tidak terjadi pemisahan fase) & Stabil (Tidak terjadi pemisahan fase) \\
e & Stabil (Tidak terjadi pemisahan fase) & Stabil (Tidak terjadi pemisahan fase) \\
$\mathrm{f}$ & Stabil (Tidak terjadi pemisahan fase) & Stabil (Tidak terjadi pemisahan fase) \\
\hline
\end{tabular}

Krim kosmetik dilakukan juga uji cycling test. Pengujian cycling test dilakukan untuk menguji kestabilan emulsi dalam sediaan krim uji, dengan melihat adanya kristalisasi atau berawan (Rieger 2000). Hasil uji cycling test krim kosmetik pada Tabel 7. dapat dilihat bahwa keseluruhan krim stabil hingga siklus ke-12. Hal ini sepadan dengan penelitan yang dilakukan oleh (Dewi, Anwar, dan Yunita 2014), bahwa krim kosmetik dengan campuran ekstrak kedelai stabil hingga siklus ke-12. Sehingga dapat disimpulkan bahwa seluruh krim kosmetik yang dibuat stabil terhadap penyimpanan pada suhu $40 \stackrel{\circ}{\mathrm{C}}$ dan $4 \stackrel{\circ}{\circ} \mathrm{C}$.

\section{KESIMPULAN}

Bahan aktif Spirulina dapat diekstraksi dengan menggunakan metode ultrasonikasi dan pengeringan dengan freeze dryer. Hasil identifikasi ekstrak mikroalga menunjukkan bahwa terdapat 3 jenis antioksidan yaitu betakaroten, fikosianin dan klorofil. Kondisi proses yang terbaik adalah menggunakan pelarut air dan waktu ultrasonikasi 15 menit, dengan menghasilkan kandungan antioksidan sebesar 452,87 $\mu \mathrm{M}$ dan aktivitas antioksidan sebesar $70,27 \%$, rendemen sebesar 37,15 gram/liter serta kandungan beta-karoten sebesar 15,98 $\mathrm{mg} / \mathrm{kg}$. Aplikasi pada krim kosmetik menunjukkan kadar beta-karoten tertinggi pada kondisi proses sonikasi selama 15 menit dengan penambahan 0,2 \% ekstrak, yaitu $4,85 \mathrm{mg} / \mathrm{kg}$ dan memilki aktivitas antioksidan 16,83 $\mu \mathrm{M}$. Secara keseluruhan krim kosmetik stabil baik dari warna, bau, tekstur, homogenitas serta penyimpanan. Selain itu krim ini juga aman digunakan karena kadar cemaran mikroba ALT dan AKK dibawah ambang batas yaitu kurang dari $10^{3} \mathrm{koloni} / \mathrm{g}$.

\section{DAFTAR PUSTAKA}

Agustini, Ni Wayan Sri. 2007. "Seminar Nasional IX Pendidikan Biologi FKIP UNS 535." In Seminar Nasional IX Pendidikan Biologi FKIP UNS, 535-43.

Badan Pengawas Obat dan Makanan Republik Indonesia. 2014. "Peraturan Kepala Badan
Pengawas Obat Dan Makanan Republik Indonesia Nomor 17 Tahun 2014 Tentang Perubahan Atas Peraturan BPOM Nomor HK. 03.1.23.07.11.6662 Tahun 2011 Tentang Persyaratan Cemaran Mikroba Dan Logam Berat Dalam Kosmetik." Kepala $B P O M$. doi:10.1017/CBO9781107415324.004.

Chaiyasut, Chaiyavat, Periyanaina Kesika, Poomchon Sakdakampanat, Sartjin Peerajan, dan Bhagavathi Sundaram Sivamaruthi. 2018. "Formulation and Evaluation of Stability of Thai Purple Rice Bran-Based Cosmetic Products." Asian Journal of Pharmaceutical and Clinical Research $11 \quad$ (1): 99. doi:10.22159/ajpcr.2018.v11i1.22073.

Dewi, R., E. Anwar, dan K.S Yunita. 2014. "Uji Stabilitas Fisik Formula Krim Yang Mengandung Ekstrak Kacang Kedelai ( Glycine Max )." Journal of Pharmaceutical Sciences and Research 1: 194-208.

Dumay, J., dan M. Morançais. 2016. "Proteins and Pigments." In Seaweed in Health and Disease Prevention. Elsivier Inc.

Fabrowska, J, B. Leska, G. Schroeder, B. Messyasz, dan M. Pikosz. 2015. "Biomass and Extracts of Algae as Material for Cosmetics." In Marine Algae Extracts: Processes, Products, and Applications, edited by Se-Kwon Kim and Katarzyna Chojnacka, First Edit, 681-706. Wiley-VCH Verlag GmbH \& Co. KGaA.

Fretes, H De, A.B. Susanto, B. Prasetyo, dan L. Limantara. 2012. "Potensi Kesehatan Aplikasi Dan Bioteknologi [ Carotenoids from Macroalgae and Microalgae: Health Potential , Application and Biotechnology ]." Jurnal Teknologi Dan Industri Pangan XXIII (2). doi:10.6066/jtip.2012.23.2.221.

Gianeti, Mirela D., dan Patricia M B G Maia Campos. 2014. "Efficacy Evaluation of a Multifunctional Cosmetic Formulation: The Benefits of a Combination of Active Antioxidant Substances." Molecules 19 (11): 18268-82. doi:10.3390/molecules191118268.

Hadiyanto, H., M.A. Marsya, dan P. Fatkhiyatul. 2015. "Jurnal Teknologi Improved Yield oF 
$\beta$-Carotene from Microalgae Spirulina Plantesis Using Ultrasound Assistes Extraction." Jurnal Teknologi 77 (1): 21922. doi:10.11113/jt.v77.4482.

Hadiyanto, Suttrisnorhadi, H. Sutanto, dan M Suzery. 2016. "Phyocyanin Extraction from Microalgae Spirulina Platensis Assisted by Ultrasound Irradiation: Effect of Time and Temperature." Songklanakarin Journal of Science and Technology 38 (4): 391-98.

Haryatfrehni, Riswi, Shinta Candra, Afra Meilianda, dan Selvi Rahmawati. 2015. "Preliminary Study the Potency of Macroalgae in Yogyakarta: Extraction and Analysis of Algal Pigments from Common Gunungkidul Seaweeds." Procedia Chemistry 14. Elsevier Ltd.: 373-80. doi:10.1016/j.proche.2015.03.051.

Henriques, M., A. Silva, dan J. Rocha. 2007. "Extraction and Quantification of Pigments from a Marine Microalga: A Simple and Reproducible Method," 586-93.

Hosikian, Aris, Su Lim, Ronald Halim, dan Michael K. Danquah. 2010. "Chlorophyll Extraction from Microalgae: A Review on the Process Engineering Aspects" 2010. doi:10.1155/2010/391632.

lbañez, El, M. Herrero, J.A. Mendiola, dan M. Castro-puyana. 2012. Extraction and Characterization of Bioactive Compounds with Health Benefi Ts from Marine Resources: Macro and Micro Algae, Cyanobacteria , and Invertebrates Bioactive Compounds from Marine Sources. Edited by M Hayes. Madrid, Spain: Springer Science+Business Media. doi:10.1007/978-1-4614-1247-2.

Kadam, Shekhar, B.K. Tiwari, dan C.P O'Dennell. 2013. "Application of Novel Extraction Technologies for Bioactives from Marine Algae." Journal of Agricultural and Food Chemistry 61: 4667-75. doi:10.1021/jf400819p.

Kerfeld, Cheryl A. 2004. "Water-Soluble Carotenoid Proteins of Cyanobacteria." Archives of Biochemistry and Biophysics $430 \quad(1)$ : $1-8$. doi:10.1016/j.abb.2004.03.018.

Lioe, H. N, S Warnasih, dan Sutanto. 2013. "Validasi Metode Analisis Beta Karoten Dengan HPLC-MWD Pada Matriks Sampel Minyak Sawit." MAKSI, 178-88.

Moldovan, Mirela, Abir Lahmar, Cătălina Bogdan, Simona Părăuan, Ioan Tomuță, dan Maria Crișan. 2017. "Formulation and Evaluation of a Water-in-Oil Cream Containing Herbal Active Ingredients and Ferulic Acid." Clujul Medical 90 (2): 212. doi:10.15386/cjmed-668.

Novak, Alessandra Cristine. 2010. "Evaluation of the Cosmetic Potential of the Cyanobacterium Spirulina Platensis." Ufpr.
Nur, M.M. Azimatun. 2014. "Potensi Mikroalga Sebagai Sumber Pangan Fungsional Di Indonesia ( Overview ) Potency of Microalgae as Source of Functional Food in Indonesia ( Overview )" XI (2): 1-6.

Oktora, A. R, W.F Ma'ruf, and T.W Agustini. 2016. "Pengaruh Penggunaan Senyawa Fiksator Terhadap Stabilitas Ekstrak Kasar Pigmen $\beta$-KAROTEN Mikroalga Dunaliella Salina Pada Kondisi Suhu Berbeda." Jurnal Pengolahan Hasil Perikanan Indonesia 19 (3): doi:10.17844/jphpi.2016.19.3.206.

206-13.

Plaza, M., S. Santoyo, M. Herrero, L. Jaime, G.G Reina, M. Herrero, F.J Señoráns, dan E. lbáñez. 2009. "Screening for Bioactive Compounds from Algae." Journal of Pharmaceutical and Biomedical Analysis 51: 450-55. doi:10.1016/j.jpba.2009.03.016

Queiroz, M.I, A.S. Fernandes, M.C. Deprá, E. Jacob-lopes, dan L.Q. Zepka. 2017. Introductory Chapter: Chlorophyll Molecules and Their Technological Relevance. Intech. doi:http://dx.doi.org/10.5772/67953.

Rahmawati, S.I., S. Hidayatulloh, dan M. Suprayatmi. 2017. "Antioksidan Extraction of Phycocyanin from Spirulina Plantesis for Biopigment and Antioxidant." Jurnal Pertanian 8 (1): 36-45.

Rahmi, D., E. Ratnawati, R. Yunilawati, dan N. N Aidha. 2014. "Peningkatan Aktivitas Anti Aging Pada Krim Nanopartikel Dengan Penambahan Bahan Aktif Alam." Jurnal Kimia Dan Kemasan 36 (2): 215-24.

Rieger, M.M. 2000. Harry's Cosmeticology. Eighth Edi. Chemical Publishing Co., Inc.

Sadeli, Richard A. 2016. "Uji Aktivitas Antioksidan Dengan Metode DPPH (1,1Diphenyl-2-Picrylhydrazyl) Ekstrak Bromelain Buah Nanas."

Sayuti, K., dan R. Yenrina. 2015. Antioksidan Alami Dan Sintetik. Andalas University Press. Padang: Andalas University Press.

Sedjati, Sri, dan Ervia Yudiati. 2012. "Profil Pigmen Polar Dan Non Polar Mikroalga Laut Spirulina Sp . Dan Potensinya Sebagai Pewarna Alami" 17 (September): 5-8.

Soares, A.T, J.G.M Júnior, R.G Lopes, R.B Derner, dan N.R.A Filho. 2016. "Improvement of the Extraction Process for High Commercial Value Pigments from Desmodesmus Sp. Microalgae." Journal of the Brazilian Chemical Society 27 (6): 1083-93 doi:10.5935/01035053.20160004 .

Standar Nasional Indonesia (SNI) 16-4399-1996. 1996. "Sediaan Tabir Surya." Dewan Standarisasi Nasional-DSN.

Velde, F. Van De, A. M Tarola, D. Guemes, dan 
M.E Pirovani. 2013. "Bioactive Compounds and Antioxidant Capacity of Camarosa and Selva Strawberries ( Fragaria x Ananassa Duch.)." Foods 2: 120-31. doi:10.3390/foods2020120.

Wulandari, P. 2016. "Uji Stabilitas Fisik Dan Kimia Sediaan Gel Semprot Ekstrak Etanol Tumbuhan Paku ( Nephrolepis Falcata (Cav.) C. Chr.)." UIN Syarif Hidayatullah, Jakarta. 